\title{
Market Definition in Banking: Recent Evidence
}

\author{
Dean F. Amel and Martha Starr-McCluer \\ Federal Reserve Board of Governors
}

February 2001

\begin{abstract}
$\underline{\text { Abstract }}$
Antitrust analysis of bank mergers defines banking markets to be geographically local and to consist of the cluster of financial products supplied by commercial banks. This definition is based on assumptions about households' and small businesses' behavior in purchasing banking services. This article utilizes data from the Survey of Consumer Finances to examine how households' use of financial services and institutions changed between 1989 and 1998. We investigate the extent to which households still focus their purchases of financial services at local depository institutions, as opposed to non-depository or distant institutions, and examine the extent to which purchases are clustered at a single institution. Overall, the results indicate that households continue, to a substantial degree, to obtain certain key asset services, notably checking accounts, at local depository institutions.
\end{abstract}

${ }^{1}$ Division of Research and Statistics, Board of Governors of the Federal Reserve System, Washington, D.C. 20551. The views expressed here are those of the authors and do not necessarily reflect those of the Board of Governors or its staff. The authors thank Myron Kwast, Marianne Bitler, Tony Cyrnak, Tim Hannan, Arthur Kennickell, Steven Pilloff, Robin Prager and Steve Rhoades for valuable comments on earlier versions of this paper. Any remaining errors are the responsibility of the authors. 


\title{
Market Definition in Banking: Recent Evidence
}

\author{
Dean F. Amel and Martha Starr-McCluer
}

\section{I. $\quad$ Introduction}

Antitrust analysis of bank mergers defines banking markets to be geographically local and to consist of the cluster of financial products supplied by commercial banks. This definition is based on assumptions about the behavior of households and small businesses when they purchase banking services. This article utilizes data from the 1998 Survey of Consumer Finances (SCF) to examine how households =lse of financial services and institutions has changed from surveys conducted from 1989 to 1995 . In particular, it investigates to what extent households still focus their purchases of financial services at local insured depository institutions, as opposed to nondepository or distant institutions. It also explores the extent to which consumers cluster their purchases of financial services at a single financial institution.

The 1990s represented a period of substantial change for the U.S. banking industry. In 1994, Congress passed the Riegle-Neal Interstate Banking and Branching Efficiency Act, which permitted nationwide banking through bank holding companies as of September 1995, and nationwide branching as of June 1997. This law was the culmination of a trend toward greater interstate banking that began with the passage of state laws in the 1980s. These laws have allowed an unprecedented merger wave to proceed in banking. The number of independent banking organizations in the United States has fallen from 12,342 at the end of 1980 to 9,221 at year-end 1990 and 6,742 at the end of 1999. Some of the firms eliminated have ranked among the largest in the country, with the BankAmerica-NationsBank, Wells Fargo-Norwest and Banc One-First Chicago NBD mergers dwarfing previous consolidations. As a result, the concentration of bank deposits in the United States has increased considerably, with the percentage of national deposits controlled by the ten largest banking organizations increasing from 20.3 percent in 1980 to 36.7 percent in 1999. In the last few years, barriers to consolidation between banking and other financial industries have also been relaxed. The Gramm-Leach- 
Bliley Act of 1999 allowed mergers among banks, securities firms and insurance companies to an extent not seen since the Glass-Steagall Act of 1933 had forced the separation of commercial and investment banking. The Citibank-Travelers merger, creating the largest banking organization in the country, was the first huge merger to take advantage of the provisions of the 1999 law.

While both interstate banking and the consolidation of the financial sector of the economy have increased concentration in banking, it is not necessarily the case that they have reduced competition in financial markets. While interstate banking has increased national concentration, most mergers have not increased concentration substantially in local banking markets. Both interstate banking laws and the Gramm-Leach-Bliley Act have introduced new potential competitors into financial markets. And developments in recent years in electronics technology and financial markets have made it easier, at least in theory, for firms to compete for more distant customers.

These legislative and technological developments raise the question of whether antitrust policy toward bank mergers should be revised to deal with the structure of the industry today. The U.S. Department of Justice and the federal bank regulatory agencies are charged with enforcing the antitrust laws in banking, under the Bank Holding Company Act, the Bank Merger Act, and other statutes. While each agency has its own procedures for analyzing the potential competitive impact of a proposed merger, all have at their core the notion of Amarket definition@ used in antitrust analysis. According to the horizontal merger guidelines of the Department of Justice and Federal Trade Commission, the relevant market in antitrust analysis is a Aproduct or group of products and a geographic area in which it is produced or sold such that a hypothetical profit-maximizing firm, not subject to price regulation, that was the only present and future producer or seller of those products in that area likely would impose at least a $\$$ mall but significant and nontransitory fincrease in price, assuming the terms of sale of all other products are held constant.

${ }^{2}$ The Citibank-Travelers merger was announced prior to passage of the Gramm-Leach-Bliley Act, but in anticipation of adoption of such a law. The merger would have had to be reversed, in part, had the law not been enacted.

${ }^{3}$ U.S. Department of Justice and the Federal Trade Commission, HoRIZONTAL MERGER 
In the case of bank mergers, the concept of market definition has been based on three considerations. ${ }^{1}$ First, markets are determined to be geographically limited, with urban markets roughly the size of a metropolitan statistical area (MSA) - a city and the suburbs around it while rural markets encompass economically integrated areas that tend to be the approximate size of one or two counties. Of course, large businesses may fairly readily use financial institutions outside of such limited areas, as may wealthy households. But markets are defined to reflect the regular use of banking services by typical households and small businesses, who face a greater practical necessity of banking close to home, work, or retail centers.

Second, the relevant product market is taken to be that set of products and services normally provided primarily by banks. The idea is that consumers tend to cluster their purchases at the institution where they have their main transactions account, and that they favor institutions offering the full range of bank products. For both theoretical reasons (bank funds are easily fungible among different types of assets) and practical reasons (they are the only data readily available for local geographic areas), total deposits are used to approximate the relative size of firms in this product market.

Third, competition from non-depository institutions is taken into account indirectly. To warrant antitrust review, a bank merger would have to raise the Herfindahl-Hirschman index (HHI), the standard measure of market concentration, by 200 points or more, to a level above 1800 (the threshold defining a highly concentrated market); in other industries, mergers only have to increase the HHI by 50 points to a level above 1800 to trigger further review. Additionally, the deposits of thrifts are often included in whole or in part in computing the HHI,

GuidELINES, April 8, 1997.

${ }^{4}$ The basis for the current approach to market definition in banking was laid in a 1963 Supreme Court ruling, United States v. Philadelphia National Bank, which found the relevant market for banking to be essentially local in nature, and the relevant product to be the set of services offered by commercial banks. For a recent review of issues in the analysis of bank mergers, see Dean F. Amel, Antitrust Policy in Banking: Current Status and Future Prospects, in BANK STRUCTURE AND COMPETITION 166 (Fed. Res. Bank of Chicago, 1997).

${ }^{5}$ The HHI is the sum of squared deposit shares within the geographic market. 
to recognize the particular source of competition they pose.

The current approach to antitrust policy has received widespread, and sometimes strong, criticism from bankers, academics, and policy makers. Technology is said to have substantially broadened feasible distances between households or small businesses and the financial institutions with which they can do business: Whereas financial transactions were previously conducted primarily in person, it is now straightforward to do business by phone, mail, ATM or computer. If technology has indeed diminished the importance of physical proximity, the local definition of banking markets may be less relevant or even obsolete. Moreover, the past two decades have seen a proliferation of products that compete with traditional bank products (such as mutual funds), and considerable entry of non-bank institutions into product lines once dominated by banks (like consumer finance and mortgage finance companies). This raises the question as to whether the "cluster" of bank services is still a relevant concept of the product market: If consumers no longer have a Asettled preference @or getting most of their financial services from full-service banks, or banks no longer dominate most product lines in the cluster, the traditional analysis may give a misleading view. Finally, analysts point out that, with barriers to entry reduced by legislative and technological developments, standard measures of concentration may be quite misleading if potential for entry is indeed much stronger than it used to be.

This article contributes to this debate by examining evidence on households =1se of financial services and institutions from the Federal Reserve Board SCF. The SCF collects very detailed information on households $\Rightarrow$ ccounts and loans, and the institutions from which they acquire them. Analysis of the 1989 and 1992 surveys provided important evidence in favor of the view that markets are local, with banks dominating most product lines in the cluster. This article presents new data from the 1998 survey, and examines how households $=$ ise of financial services and institutions has changed from earlier surveys. In particular, we investigate to what extent households still (1) focus their purchases of financial services at insured depositories, as opposed to non-depository institutions; (2) purchase their financial services locally; and (3) tend

\footnotetext{
${ }^{6}$ See Amel, supra note 4.
} 
to cluster their purchases of financial services at a single Aprimary@inancial institution.

The next section reviews the literature. Section III briefly describes the data. Sections IV, V and VI examine, respectively, consumers' relative use of depository and non-depository institutions, their use of local and non-local financial providers, and the extent to which they cluster their financial services with one provider. Overall, the results indicate that households continue, to a substantial degree, to obtain and to prefer to obtain certain key household asset services, notably checking accounts, at local depository institutions. Section VII concludes and suggests some directions for future research.

\section{II. $\quad$ Previous research on banking markets}

Many studies over the years have documented a relationship between interest rates and concentration across metropolitan areas. In a study based on data from the 1980s, Berger and Hannan found that deposit rates tended to be lower in metropolitan areas where the banking industry was relatively concentrated, controlling for other factors that might affect interest rates. Using data on loan rates from 20 cities in 1987-88, Rhoades similarly found that mortgage interest rates tended to be higher in cities where concentration was relatively high. ${ }^{\mathrm{B}}$ This strong empirical regularity provided support for the view of banking markets as geographically local.

Survey data, showing that households and small businesses tend to bank quite close to their homes and workplaces, provided further evidence in favor of the local view. Analyzing data from the $1989 \mathrm{SCF}$, Elliehausen and Wolken found that 50 percent of households lived or worked within 2 miles of the institution where they had their checking account, and 75 percent were within 11 miles. ${ }^{6}$ Additionally, a high proportion of households had more than one account or loan at their checking-account institution, consistent with the notion of clustering. In a separate study based on the 1988-89 National Survey of Small Business Finances, Elliehausen

${ }^{7}$ Allen N. Berger and Timothy H. Hannan, The Price-Concentration Relationship in Banking, 71 REV. ECON. AND STAT. 291 (1989).

${ }^{8}$ Stephen A. Rhoades, Evidence on the SizE of BANKIng MARKETS FROM MortGaGE RAtes In TwEnty Cities (FeD. Res. BoArd StAFF Study No. 162, 1992).

${ }^{9}$ Gregory E. Elliehausen and John D. Wolken, Banking Markets and the Use of Financial 
and Wolken showed that small- and medium-sized businesses were usually quite close to the financial institutions with which they did business. ${ }^{\square}$ Kast, Starr-McCluer, and Wolken updated these studies, finding that, as of the early 1990s, households $\approx$ and small businesses $=1 \mathrm{se}$ of financial services had changed only modestly.

One shortcoming of using survey data to define markets is that such data measure current behavior, not the likely actions of households in reaction to price changes by current suppliers. This means that survey results measure service areas of firms rather than true economic markets. The service areas of firms provide a lower bound for the geographic extent of economic markets, but markets may be larger if households readily switch to more distant suppliers of banking services. Evidence on the price sensitivity of bank customers is mixed. Estimation of the elasticity of demand for bank deposits has shown that demand is quite inelastic. ${ }^{12}$ On the other hand, price has been found to be one of the primary determinants of the choice of households when forming deposit relationships. 13

Some recent studies suggest that the geographic reach of banking markets has broadened in the 1990s. Radecki showed that, in some states, large banks now set interest rates on a statewide basis, suggesting a reduction in sensitivity to variations in local market conditions. Also, using data for 1996, he found no significant correlation between interest rates and concentration across metropolitan areas. ${ }^{14}$ Cyrnak and Hannan analyzed data on small business loans collected under the Community Reinvestment Act, documenting a notable rise in lending

Services by Households, 78 FED. RES. BULL. 169 (1992).

${ }^{10}$ Gregory E. Elliehausen and John D. Wolken, Banking Markets and the Use of Financial Services by Small and Medium-Sized Businesses, 76 FED. RES. BuLL. 801 (1990).

${ }^{11}$ Myron L. Kwast, Martha Starr-McCluer, and John D. Wolken, Market Definition and the Analysis of Antitrust in Banking, 42 ANTITRUST BuLl. 973 (1997).

${ }^{12}$ Dean F. Amel and Timothy H. Hannan, Establishing Banking Market Definitions through Estimations of Residual Deposit Supply Equations 23 J. BANKING AND FINANCE 1667 (1999).

${ }^{13}$ Elizabeth K. Kiser, Switching Costs in Household Deposit Relationships: Evidence from Survey Data, mimeo (November 2000).

${ }^{14}$ Lawrence J. Radecki, The Expanding Geographic Reach of Retail Banking Markets, 4 Fed. Res. BANK OF New York Econ. Policy ReV. (1998). 
shares of out-of-market institutions between 1996 and 1998..$^{15}$ Petersen and Rajan found that, among small businesses surveyed in 1993, recently established banking relationships were less likely to be with a local institution than relationships begun some time ago.

While these studies suggest some broadening in geographic reach, it is not clear that trends to date necessarily warrant a departure from the current approach to market definition. As Heitfield points out, the data showing uniformity of prices cited by Radecki do not necessarily imply that markets are geographically large, and evidence from smaller banks operating in these markets supports local geographic markets. ${ }^{10}$ Also, the current approach does not assume strictly local markets, but rather that geographical constraints on households and small businesses are of sufficient degree to imply pricing power within metropolitan areas. Similarly, allowance is already made for competition from non-bank institutions; the question is whether current methods appreciably understate its scope or extent. Thus, it would be valuable to know (1) whether depositories still occupy a central position in households =tse of financial services, (2) whether trends toward use of more distant institutions are broad-based across products and across consumers, and (3) whether the practice of clustering the purchase of banking services is still widespread. In this regard, updated survey evidence has the potential to be quite informative.

\section{The Survey of Consumer Finances}

The Survey of Consumer Finances (SCF) is a triennial survey sponsored by the Federal Reserve Board. The survey collects detailed information on households $\approx$ assets, liabilities, use of financial services, and other financial characteristics. ${ }^{16}$ Since 1989 , respondents have been asked about the financial institutions they use, including the type of institution and its distance, up to 50

${ }^{15}$ Anthony Cyrnak and Timothy Hannan, Non-Local Lending to Small Business, mimeo (June 2000).

${ }^{16}$ Mitchell A. Petersen and Raghuram G. Rajan, Does Distance Still Matter? The Information Revolution in Small Business Lending (NBER Working Paper No. 7685, May 2000).

${ }^{17}$ Erik A. Heitfield, What Do Interest Rate Data Say about the Geography of Retail Banking Markets? 44 ANTITRUST BuLL. 333 (1999).

${ }^{18}$ For a general description of the SCF, see Arthur Kennickell, Martha Starr-McCluer, and Brian Surette, Recent Changes in U.S. Family Finances: Results from the 1998 Survey of 
miles, from the home or office of the person who uses it most. ${ }^{19}$ These questions are asked at the outset of the survey, so that when respondents are asked detailed questions on their loans and accounts, they can refer back to the institution at which each item is held. ${ }^{20}$ This provides rich insights into households fuse of financial institutions, and the changes therein over time.

For purposes of this study, we divide institutions into depository and non-depository institutions. 21 Depositories include commercial banks, thrift institutions (savings and loan associations and savings banks), and credit unions. Non-depositories include finance companies, brokerages, mortgage and real estate lenders, and other institutions. Because our interest is in markets for financial services typically supplied by banks, the analysis focuses on certain financial services for which banks have traditionally been dominant or important providers. These include checking accounts, savings accounts, money market accounts (both money market deposit accounts and money market mutual funds), certificates of deposit (CDs), IRA and Keogh accounts, brokerage accounts, trusts and other managed assets (including annuities), first and second mortgages, motor vehicle loans, home equity and other lines of credit, and other consumer loans.

Consumer Finances, 86 FED. RES. BULL. 1 (2000).

${ }^{19}$ Detailed information is collected for a maximum of six institutions. Both institution type and distance are self-reported, and so may sometimes be reported inaccurately from the analyst's perspective: For example, a respondent may report a non-bank mortgage subsidiary of a bank as a finance company; another may report distance to a loan-servicing office, rather than to the office that originated the loan. Conceivably, this may result in some overstatement of the declining relative importance of banks or local institutions. Nonetheless, results from the National Survey of Small Business Finances -- in which institution type and distance for banks, thrift institutions and credit unions are determined from external sources -- show trends quite similar to those in the SCF, so it seems unlikely that those observed in the SCF are an artifact of reporting (see Kwast, Starr-McCluer, and Wolken, supra note 11).

${ }^{20}$ Institution information is also collected if an institution is mentioned during the interview that was not reported at the outset of the survey.

${ }^{21}$ Detailed definitions of institution types are given in the Appendix.

${ }^{22}$ Detailed definitions of account and loan types are given in the Appendix. One service of potential interest that we cannot cover adequately is credit cards: The SCF does not collect detailed information on institutions used for credit cards only. 


\section{Depository versus non-depository institutions}

Table 1 shows the shares of households using various types of institutions from 1989 to 1998. 23 Among households having bank-type accounts or loans, 98 percent used a depository institution in 1998 -- a figure that has hardly changed since 1989. The share of households using a commercial bank actually rose from 1989 to 1998, in part reflecting a shift away from thrifts toward banks and credit unions. 24 At the same time, the share of households using a nondepository increased substantially, from below one-third in 1989 to almost two-thirds in 1998. Shares more than doubled for all types of non-depositories, including finance companies, brokerages, mortgage companies, and other non-depositories.

To understand the factors underlying growing use of non-depositories, it is useful to examine specific types of bank-type accounts and loans and the institutions from which they were acquired (Table 2). Checking accounts remained overwhelmingly provided by depositories: In both 1989 and 1998, over 98 percent of checking accounts were at depository institutions. Savings accounts and CDs also remained quite concentrated at depositories, with depositories= shares at 95 percent or higher in both 1989 and 1998. However, other types of accounts registered appreciable reductions in shares provided by depositories: The share of money market accounts declined from 82 percent to 69 percent; the share of IRA/Keogh accounts dropped substantially, from three-quarters to two-fifths, with the brokerage category picking up the lost share; and depositories $=$ hares of brokerage and trust accounts also dipped. These run-offs reflect a number of trends during this period, notably the growing use of IRAs for 401(k) rollovers, and the shift toward mutual funds and other equity-based investments for such

${ }^{23}$ Here and throughout this paper, analysis is confined to households having at least one bank-type account or loan, as defined above, from an institutional source. All descriptive statistics presented here use weights that make the sample representative of the population as a whole (see Kennickell, Starr-McCluer, and Surette, supra note 18).

${ }^{24}$ The consolidation of the financial services sector in the 1980s and 1990s has affected thrifts to a greater extent than banks or credit unions. The shift away from thrifts found in the survey data is likely due to the decline in the number and size of thrifts relative to banks and credit unions rather than to disproportionate dissatisfaction with the performance of thrifts. 
accounts. ${ }^{25}$ In terms of bank-type loans, depositories $=$ hares declined substantially for mortgages, vehicle loans, and other consumer loans, as loans shifted to mortgage and consumer finance companies and other non-depository institutions; only for lines of credit (home equity and other) did depositories $=$ hare remain above 80 percent. These shifts reflect a number of factors that have served to broaden the scope of credit markets in the past 10-15 years, including automated credit scoring, securitization, and broad-based advertising and solicitation.

Nonetheless, the trend away from depositories may be somewhat overstated here, since some institutions identified as Afinance companies @may be non-bank subsidiaries of banks. 26

On balance, while depositories certainly remain the most widely used institution type, use of other institutions has grown considerably, especially for IRA/Keogh accounts and most types of loans. Depositories clearly remain dominant providers of checking and savings accounts and CDs, and to some extent lines of credit.

\section{Local versus non-local institutions}

As mentioned, previous research found that distances between households and their depository institutions have typically been quite short. The 1998 survey shows virtually no change in this regard: The median distance between households and their depository institutions was 3 miles in 1998, unchanged from 1989 (Table 3). However, distances have tended to drift up at the upper end of the distribution, with the $75^{\text {th }}$ percentile rising from 8 to 10 miles and the $90^{\text {th }}$ percentile rising from 25 to $50+$ miles. All types of depositories showed this stability in the middle of the distribution of distances, with some upward drift in distances at the upper end. In contrast, the median distance between households and the non-depository institutions they use

\footnotetext{
${ }^{25}$ For further discussion, see Carol Bertaut and Martha Starr-McCluer, Household
} Portfolios in the U.S., in L. Guiso, M. Haliassos, and T. Jappelli, eds., HousEHOLD PORTFOLIOS (Cambridge, MA: MIT Press, forthcoming, 2001). Of course, returns to stock-based assets were unusually large between 1989 and 1998, with the S\&P 500 rising at an average annual rate of 17.8 percent, compared to an average rate on a 6-month CDs of 5.8 percent. Conceivably, the shift away from depositories may slow, or even be reversed, should the pace of stock-market gains fall off.

${ }^{26}$ See supra note 19. 
rose substantially, from 20 miles in 1989 to 50+ miles in 1998. The rise was particularly apparent for finance companies and brokerages; the median distance to a mortgage company was already at 50+ miles in 1989. Thus, the data show a shift toward institutions at greater distances, but mostly on the non-depository side.

Again, examining the types of services acquired at local and non-local institutions provides insights into these trends (Table 4). Here an institution is considered to be Aocal@f it is within 30 miles of the home or workplace of the household member who uses it the most. In 1998, about 94 percent of checking accounts were acquired from local institutions, down a bit from 97 percent in 1989. Shares of savings accounts and CDs acquired from local institutions also slipped modestly, while the share of money market accounts fell more appreciably from 91 to 80 percent. ${ }^{27}$ But IRA/Keogh accounts registered a pronounced decline, with the share falling from 88 percent in 1989 to 66 percent in 1998, again reflecting the shift toward mutual funds and other equity-based investments. The shares of loans acquired from local institutions also dropped markedly, with shares of mortgages, vehicle loans, and other consumer loans all falling by more than 20 percentage points; only for lines of credit did local institutions $=$ hare remain above 80 percent.

As Table 4 uses accounts and loans as the unit of analysis, it does not directly gauge whether the shift toward non-local institutions is broad-based across households, or whether it is driven by a subset of households with a disproportionate share of accounts and loans. Thus, Tables 5 and 6 examine shares of households using local and non-local institutions. Virtually all households used a local financial institution in both 1989 and 1998 (Table 5). In both years, the

${ }^{27}$ The survey does not distinguish between money market deposit accounts and money market mutual funds held at depositories, so the relative importance of these two products in causing this trend is not known.

${ }^{28}$ For local depositories specifically, their share of checking accounts slipped a bit between 1989 and 1998, from 96 percent to 93 percent, while their shares of savings accounts and CDs remained around 90 percent. Local depositories' share of lines of credit also moved down, but remained at 73 percent in 1998. In contrast, local depositories' share of IRA/Keogh accounts fell from 70 percent to 37 percent; their share of mortgage loans dropped from 68 to 42 percent; their share of vehicle loans declined from 77 percent to 50 percent; and their share of other consumer loans plunged from 74 percent to 27 percent. 
share of households using a local depository was above 95 percent, and the share using a local commercial bank exceeded three-fourths. While non-local institutions are not as widely used as local institutions, their use has grown substantially over time: More than one-half of households used a non-local institution in 1998, up from about one-quarter in 1989. The use of non-local depositories climbed from 15 percent of households in 1989 to 26 percent of households in 1998, while the use of non-local non-depositories rose by more than 30 percentage points, from 11 percent of households in 1989 to 42 percent in 1998.

As might be expected, households that were younger or better-off showed the largest increases in use of non-local institutions (Table 6). In 1998, households in the top quarter of the income distribution were twice as likely to use a non-local institution as those in the bottom quarter. Similarly, those in the under-35 age range were almost twice as likely as those in the 65and-over group to use a distant firm. Even so, use of non-local institutions has increased across the age and income distributions; for example, even in the bottom quarter of the income distribution and in the 65+ age group, the share of households using a non-local institution rose more than 15 percentage points between 1989 and 1998.

In sum, the data show growing use of institutions located at greater distances. While the use of non-local depositories has grown somewhat, it is the use of non-local non-depositories that has increased dramatically. Nonetheless, for a core of bank-type products, these trends are hardly discernible: For checking accounts, savings accounts, and CDs, 90 percent of services are still acquired within the local market.

\section{Clustering of financial services}

As mentioned, the courts and antitrust agencies have defined the relevant product market in bank mergers to be the full range of financial services offered by commercial banks. This approach is based on the notion that bank customers cluster their purchases at their primary depository institution, due to a cost advantage or settled consumer preference for acquiring services jointly.

We can gain some insight into the empirical importance of clustering by looking at 
households Aprimary@institutions and what business they do there. ${ }^{29}$ The types of institutions used by households as their primary institution have not changed much over time (Table 7). In 1998, about 95 percent of households identified a depository as their primary institution, down only a nick from 97 percent in 1989. The share using a commercial bank rose from 65 percent in 1989 to 67 percent in 1998, while the share using a credit union rose from 10 percent to 16 percent; again these trends partly reflect a shift away from thrifts, for which the share dropped from 22 percent to 12 percent.

The share of households having accounts or loans at institutions other than their primary institution rose from 71 percent in 1989 to 82 percent in 1998. Use of non-primary depositories held steady at a bit below two-thirds of households. In contrast, use of non-primary nondepositories soared, from about one-fourth of households in 1989, to almost three-fifths in 1998. All types of non-depositories registered large gains. This suggests that, at least for some financial products, households are less tied to obtaining services from their primary financial institution than they were ten years ago.

Concerning the tendency to cluster use of financial services at the primary institution, here the evidence from the survey is somewhat mixed. On one hand, the share of all accounts and loans acquired at primary institutions has tended to decline over time B from 56 percent in 1989 to 47 percent in 1998 (Table 8). Again, the experience differs considerably across the different types of accounts and loans. The share of checking accounts acquired from the primary institution held steady from 1989 to 1998 , just below three-quarters. The shares for savings accounts, money market accounts, CDs, and lines of credit fluctuated somewhat, but remained above 50 percent in 1998 . In contrast, the share for IRA/Keogh accounts declined from twofifths to one-quarter, and the shares for mortgages, vehicle loans, and other consumer loans also fell substantially.

On the other hand, it remains true that a majority of households consume more than one service at their primary institution. Table 9 shows the percentage of households that obtain a

${ }^{29}$ The primary institution is identified by the respondent as that at which the household does the most business. 
particular service from their primary institution, conditional on the number of services obtained from that institution. For example, for 85 percent of households that obtained three services from their primary institution in 1998, a checking account was one of those three services. The last column of the table shows that the share of households having more than one service at the primary institution rose somewhat between 1989 and 1998, from 57 percent to 64 percent. Of those households having more than one service at the primary institution, most had two or three services; in 1998, as in 1989, the most common combination of services was a checking account with a savings account, but many other combinations of accounts and loans occur. Thus, while the share of bank-type services acquired from the primary institution has fallen since 1989, the tendency to acquire more than one service from the primary institution has not weakened over time. This suggests that, although consumers may still have some settled preference for acquiring services together, this preference has probably decreased in relative importance.

\section{Summary and implications}

Evidence from the 1998 Survey of Consumer Finances suggests that for some services, such as checking accounts, households still use depository institutions almost exclusively. However, for other services, including all types of loans other than lines of credit, banks appear to face increasing competition from non-depositories. Similarly, households still rely almost totally on local financial firms for some services, but increasingly use non-local providers for other services. Furthermore, the services that tend to be purchased only from depositories tend to be the same services that are acquired locally. For these products - mainly transactions accounts, CDs, and lines of credit - it appears that the current approach of antitrust authorities in defining local markets limited to depository institutions still accurately reflects competitive conditions.

Survey results on the clustering of financial services do not provide such clear support for current policy. While the number of financial services that households purchase from their primary institutions has increased, the percentage of services purchased at the primary institution has dropped in recent years. The greater-than-proportional increase in purchases from nonprimary suppliers that this reflects has been particularly strong for investments such as 
IRA/Keogh accounts, which tend to be long-term, and for most types of loans. Thus, there is some evidence that the premise underlying the entire cluster of banking products as the proper product market definition is weakening over time.

If antitrust authorities continue to rely on the cluster of bank products as the relevant product market definition, despite the increasing reliance of households on multiple providers of financial services, it will likely become increasingly difficult to maintain that only local depository institutions should be considered competitors in the market. If, on the other hand, a narrower definition of the cluster is utilized or if product lines such as transactions accounts are considered separate product markets, it is clear that, at present, some important markets continue to be restricted to local depositories.

There are important caveats to this conclusion. These results reflect current behavior, but do not show what would happen if local institutions were to raise prices in unison. Thus, the results measure service areas of firms rather than true economic markets, and further research on the price-sensitivity of financial customers is needed. Also, this research only examines the behavior of households. Small businesses are very important consumers of bank services, and may be more or less constrained to the use of local depositories or more or less prone to cluster their purchases than are the households surveyed here. Finally, recent developments in electronic technologies have been very rapid and could quickly make results based on a 1998 survey obsolete. Future research will be needed to assess the effects of technological developments. 


\section{Appendix}

Item

$\underline{\text { Institution types }}$

Commercial banks

Thrifts

Credit unions

Finance companies

Brokerages

Mortgage companies

Other non-depositories

Account types

Checking accounts

Savings accounts

Money market accounts

Certificates of deposit

IRA/Keogh

Brokerage

Trusts

Mortgages

Vehicle loans

Lines of credit

Other loans

Other items

Primary institution

Distance

\section{Definition}

Note: Institution types are identified by respondents in response to the question, AWhat kind of institution is this? Is it a commercial bank, a savings and loan or savings bank, a credit union, a finance or loan company, a brokerage, or what? @f the respondent does not know the institution type but has provided the institution name, the type can usually be identified by survey staff.

Commercial banks and trust companies.

Savings banks, and savings and loans companies.

Credit unions.

Consumer finance, auto finance, loan, and student loan companies.

Brokerages, mutual fund companies, and insurance companies.

Mortgage companies and real estate lenders. Includes some mortgage institutions recorded as finance companies (see Kennickell et al., supra note 18, at 25).

Government agencies, retail establishments, collection agencies, leasing companies, foreign institutions, miscellaneous farm lenders, and miscellaneous other institutions.

Checking accounts other than money market.

Includes passbook accounts, share accounts, Christmas Club accounts, and any other type of savings account.

Money market deposit accounts and money market mutual funds.

Short- and long-term CDs.

Individual Retirement Accounts and Keogh accounts, including accounts established as pension rollovers.

Accounts for the purchase or sale of stocks and other securities.

Trusts, annuities, and management investment accounts in which the household has an equity interest.

First and second mortgages and home equity loans on the primary residence, and loans for other real estate.

Loans for the purchase of any type of vehicle (autos, vans, trucks, sport utility vehicles, motorcycles, recreational vehicles, airplanes, and boats) owned for personal use.

Home equity and other lines of credit.

Loans for home improvement or repair, student loans, installment loans, personal loans. (Note that the SCF does not collect information on credit card institutions).

Institution identified in response to the question, AWhat is the name of the financial institution where you [and your family living here] do the most business?@

Respondents are asked, ARoughly, how many miles is the office or cash machine of this institution from the home or workplace of the person who uses it most often? (We want the closer of the distance from the home or workplace).@Distances are recorded up to a maximum of 50 miles. Included in the $50+$ category are institutions located in foreign countries and those dealt with by toll-free phone number, post office box, or the Internet. 
Table 1. Percentage of households using institutions of different types, 1989-1998

Percentage of households using an institution of this type

$\begin{array}{lrrrr} & \underline{1989} & \underline{1992} & \underline{1995} & \underline{1998} \\ \text { All institutions } & 100.0 & 100.0 & 100.0 & 100.0 \\ \text { Depositories } & 99.2 & 99.2 & 99.3 & 98.4 \\ \quad \text { Commercial banks } & 78.7 & 85.2 & 85.2 & 83.2 \\ \text { Thrift institutions } & 42.7 & 31.0 & 25.1 & 23.5 \\ \text { Credit unions } & 30.6 & 35.7 & 38.8 & 36.8 \\ & & & & \\ \text { Non-depositories } & 27.5 & 42.1 & 51.3 & 62.3 \\ \text { Finance companies } & 7.8 & 12.7 & 18.2 & 22.9 \\ \text { Brokerage firms } & 15.0 & 22.3 & 28.3 & 34.9 \\ \text { Mortgage finance companies } & 6.2 & 14.3 & 15.7 & 21.2 \\ \text { Other non-depositories } & 0.9 & 2.3 & 2.2 & 4.9\end{array}$

Note: Excludes households that do not use financial services provided by an institutional source. 
19

Table 2. Share of services acquired from different types of institutions, by type of service, 1989 and 1998

\begin{tabular}{|c|c|c|c|c|c|}
\hline & & are of services & deposit & & \\
\hline 1989 & $\underline{\text { All }}$ & $\begin{array}{c}\text { Commercial } \\
\text { banks }\end{array}$ & Thrifts & $\begin{array}{l}\text { Credit } \\
\text { unions }\end{array}$ & $\underline{\text { All }}$ \\
\hline All accounts & 91.0 & 53.1 & 23.9 & 14.1 & 9.0 \\
\hline Checking & 99.3 & 68.6 & 20.2 & 10.5 & 0.7 \\
\hline Savings & 99.0 & 43.2 & 26.0 & 29.8 & 1.0 \\
\hline Money market & 82.1 & 47.0 & 25.8 & 9.3 & 17.9 \\
\hline $\mathrm{CDs}$ & 96.7 & 50.1 & 39.4 & 7.3 & 3.3 \\
\hline IRA/Keogh & 74.8 & 42.8 & 24.2 & 7.8 & 25.2 \\
\hline Brokerage & 10.1 & 8.5 & 0.8 & 0.8 & 89.9 \\
\hline Trusts & 46.8 & 28.8 & 8.9 & 9.0 & 53.2 \\
\hline All loans & 85.4 & 45.9 & 23.3 & 16.1 & 14.6 \\
\hline Mortgages & 80.9 & 40.4 & 36.1 & 4.4 & 19.1 \\
\hline Vehicle & 90.3 & 52.3 & 11.6 & 26.3 & 9.7 \\
\hline Lines of credit & 89.5 & 52.3 & 15.7 & 21.5 & 10.5 \\
\hline Other loans & 84.5 & 42.5 & 17.8 & 24.2 & 15.5 \\
\hline Accts \& loans & 89.8 & 51.5 & 23.7 & 14.5 & 10.2 \\
\hline$\underline{1998}$ & $\underline{\text { All }}$ & $\begin{array}{l}\text { Commercial } \\
\underline{\text { banks }}\end{array}$ & $\underline{\text { Thrifts }}$ & $\begin{array}{l}\text { Credit } \\
\text { unions } \\
\end{array}$ & All \\
\hline All accounts & $\overline{81.7}$ & $\overline{51.5}$ & 10.5 & $\overline{19.7}$ & $1 \overline{8.3}$ \\
\hline Checking & 98.4 & 69.5 & 11.5 & 17.4 & 1.6 \\
\hline Savings & 97.9 & 49.1 & 12.9 & 35.9 & 2.1 \\
\hline Money market & 68.5 & 50.0 & 8.5 & 10.1 & 31.5 \\
\hline CDs & 94.8 & 65.0 & 16.7 & 13.0 & 5.2 \\
\hline IRA/Keogh & 41.8 & 25.7 & 6.2 & 9.9 & 58.2 \\
\hline Brokerage & 7.4 & 6.3 & 0.6 & 0.4 & 92.6 \\
\hline Trusts & 26.4 & 19.1 & 3.4 & 3.9 & 73.6 \\
\hline All loans & 57.7 & 37.3 & 8.3 & 12.1 & 42.3 \\
\hline Mortgages & 56.1 & 39.5 & 12.2 & 4.5 & 43.9 \\
\hline Vehicle & 65.5 & 36.3 & 4.9 & 24.4 & 34.5 \\
\hline Lines of credit & 82.1 & 52.0 & 11.6 & 18.5 & 17.9 \\
\hline Other loans & 36.4 & 26.2 & 3.5 & 6.7 & 63.6 \\
\hline Accts \& loans & 74.9 & 47.5 & 9.9 & 17.6 & 25.1 \\
\hline
\end{tabular}

\begin{tabular}{|c|c|c|c|}
\hline $\begin{array}{c}\text { Finance } \\
\text { companies }\end{array}$ & Brokerages & $\begin{array}{l}\text { Mortgage } \\
\text { companies }\end{array}$ & Other \\
\hline 0.2 & 8.6 & 0.1 & 0.1 \\
\hline 0.1 & 0.5 & 0.1 & 0.0 \\
\hline 0.1 & 0.9 & 0.0 & 0.0 \\
\hline 0.1 & 17.3 & 0.0 & 0.5 \\
\hline 0.1 & 3.2 & 0.0 & 0.0 \\
\hline 0.4 & 24.2 & 0.5 & 0.1 \\
\hline 0.6 & 89.0 & 0.0 & 0.3 \\
\hline 5.9 & 47.3 & 0.0 & 0.0 \\
\hline 5.6 & 0.8 & 7.8 & 0.3 \\
\hline 0.2 & 0.5 & 17.8 & 0.6 \\
\hline 9.2 & 0.2 & 0.3 & 0.0 \\
\hline 5.4 & 3.3 & 1.7 & 0.0 \\
\hline 14.3 & 0.4 & 0.3 & 0.5 \\
\hline 1.4 & 6.9 & 1.8 & 0.1 \\
\hline Finance & & Mortgage & \\
\hline companies & Brokerages & companies & Other \\
\hline 0.5 & 17.6 & 0.1 & 0.1 \\
\hline 0.2 & 1.2 & 0.1 & 0.0 \\
\hline 0.2 & 1.8 & 0.1 & 0.0 \\
\hline 0.6 & 30.6 & 0.1 & 0.1 \\
\hline 0.3 & 4.5 & 0.0 & 0.3 \\
\hline 1.5 & 56.3 & 0.2 & 0.3 \\
\hline 0.9 & 91.7 & 0.0 & 0.0 \\
\hline 1.4 & 71.0 & 0.0 & 1.2 \\
\hline 19.0 & 1.3 & 18.5 & 3.6 \\
\hline 0.0 & 1.1 & 42.6 & 0.2 \\
\hline 32.3 & 0.3 & 0.4 & 1.5 \\
\hline 7.4 & 3.0 & 5.0 & 2.5 \\
\hline 46.4 & 2.2 & 0.4 & 14.6 \\
\hline 5.7 & 13.0 & 5.3 & 1.1 \\
\hline
\end{tabular}


Table 3. Distances from institutions used, by institution type, 1989 and 1998

Distance in miles, by percentile:

\begin{tabular}{|c|c|c|c|c|}
\hline$\underline{1989}$ & $\underline{25^{\text {th }}}$ & $\underline{\text { Median }}$ & $\underline{75^{\text {th }}}$ & $\underline{90^{\text {th }}}$ \\
\hline Depositories & 1 & 3 & 8 & 25 \\
\hline Commercial banks & 0 & 2 & 7 & 20 \\
\hline Thrift institutions & 1 & 3 & 7 & 22 \\
\hline Credit unions & 1 & 5 & 18 & 50 \\
\hline Non-depositories & 6 & 20 & 50 & 50 \\
\hline Finance companies & 3 & 10 & 50 & 50 \\
\hline Brokerage firms & 5 & 15 & 50 & 50 \\
\hline Mortgage finance companies & 15 & 50 & 50 & 50 \\
\hline Other non-depositories & 15 & 31 & 50 & 50 \\
\hline$\underline{1998}$ & $\underline{25^{\text {th }}}$ & $\underline{\text { Median }}$ & $\underline{75^{\text {th }}}$ & $90^{\text {th }}$ \\
\hline Depositories & 1 & 3 & 10 & 50 \\
\hline Commercial banks & 0 & 3 & 8 & 50 \\
\hline Thrift institutions & 0 & 3 & 10 & 50 \\
\hline Credit unions & 2 & 6 & 20 & 50 \\
\hline Non-depositories & 10 & 50 & 50 & 50 \\
\hline Finance companies & 16 & 50 & 50 & 50 \\
\hline Brokerage firms & 7 & 40 & 50 & 50 \\
\hline Mortgage finance companies & 40 & 50 & 50 & 50 \\
\hline Other non-depositories & 4 & 14 & 50 & 50 \\
\hline
\end{tabular}

Note: Distances are recorded up to a maximum of 50 miles. 
Table 4. Shares of services acquired from local institutions and local depositories, by type of service, $1989-98$

$\underline{\text { Share of services acquired from a: }}$

\begin{tabular}{|c|c|c|c|c|c|c|c|c|}
\hline & \multicolumn{4}{|c|}{ Local institution } & \multicolumn{4}{|c|}{ Local depository institution } \\
\hline & 1989 & 1992 & 1995 & 1998 & 1989 & 1992 & 1995 & 1998 \\
\hline All accounts \& loans & 90.4 & 83.9 & 79.7 & 77.6 & 83.6 & 75.2 & 70.3 & 67.1 \\
\hline All accounts & 93.0 & 88.2 & 85.8 & 85.5 & 86.5 & 79.9 & 76.7 & 76.0 \\
\hline Checking & 96.8 & 94.5 & 93.5 & 94.2 & 96.4 & 94.0 & 92.7 & 93.3 \\
\hline Savings & 92.4 & 88.5 & 87.7 & 90.8 & 91.7 & 87.2 & 86.5 & 89.8 \\
\hline Money market & 90.9 & 84.9 & 81.8 & 79.7 & 78.4 & 71.7 & 66.0 & 63.6 \\
\hline CDs & 94.0 & 91.7 & 89.8 & 91.1 & 91.7 & 88.9 & 87.6 & 88.0 \\
\hline IRA/Keogh & 87.7 & 76.9 & 69.1 & 65.5 & 70.3 & 53.0 & 42.4 & 37.2 \\
\hline Brokerage & 80.3 & 73.2 & 66.0 & 60.2 & 9.4 & 8.7 & 5.9 & 6.3 \\
\hline Trusts & 55.2 & 62.2 & 60.4 & 57.8 & 29.5 & 32.1 & 22.9 & 22.1 \\
\hline All loans & 81.1 & 71.9 & 64.1 & 57.7 & 73.3 & 61.9 & 54.0 & 44.8 \\
\hline Mortgages & 76.2 & 67.8 & 59.5 & 53.3 & 68.3 & 57.5 & 50.2 & 42.3 \\
\hline Vehicles & 82.7 & 76.8 & 66.0 & 61.3 & 76.9 & 68.6 & 56.2 & 50.2 \\
\hline Lines of credit & 86.6 & 85.1 & 83.3 & 82.6 & 80.0 & 77.9 & 78.1 & 73.4 \\
\hline Other loans & 86.6 & 64.2 & 60.9 & 48.9 & 73.9 & 50.0 & 45.6 & 26.9 \\
\hline
\end{tabular}


Table 5. Percentage of households using local and non-local financial institutions, 1989-98

Percentage of households using:

\begin{tabular}{lrrrr|rrrr} 
& \multicolumn{3}{c}{ Local institution } & \multicolumn{5}{c}{ Non-local institution } \\
& $\underline{1989}$ & $\underline{1992}$ & $\underline{1995}$ & $\underline{1998}$ & $\underline{1989}$ & $\underline{1992}$ & $\underline{1995}$ & $\underline{1998}$ \\
All institutions & 99.1 & 98.4 & 98.2 & 98.4 & 23.7 & 39.9 & 46.4 & 54.2 \\
Depositories & 98.4 & 97.7 & 97.3 & 96.9 & 15.1 & 24.2 & 26.3 & 25.8 \\
Commercial banks & 76.5 & 82.0 & 81.7 & 79.8 & 7.4 & 13.9 & 16.3 & 16.3 \\
Thrift institutions & 40.5 & 27.7 & 21.7 & 20.3 & 4.0 & 4.8 & 4.4 & 4.5 \\
Credit unions & 26.4 & 29.1 & 31.5 & 30.6 & 5.4 & 9.0 & 9.5 & 8.2 \\
& & & & & & & & \\
Non-depositories & 18.9 & 26.3 & 30.7 & 35.2 & 11.4 & 23.6 & 30.5 & 42.4 \\
Finance companies & 5.7 & 7.9 & 9.5 & 9.9 & 2.3 & 5.8 & 9.9 & 15.1 \\
Brokerages & 10.3 & 14.7 & 18.8 & 20.7 & 5.8 & 10.6 & 13.2 & 19.9 \\
Mortgage companies & 3.0 & 5.0 & 4.4 & 6.2 & 3.4 & 9.6 & 11.4 & 15.7 \\
Other & 0.6 & 1.1 & 1.3. & 3.1 & 0.4 & 1.2 & 0.9 & 1.9
\end{tabular}


Table 6. Share of households using local and non-local institutions, by age of head and income percentile, 1989 and 1998

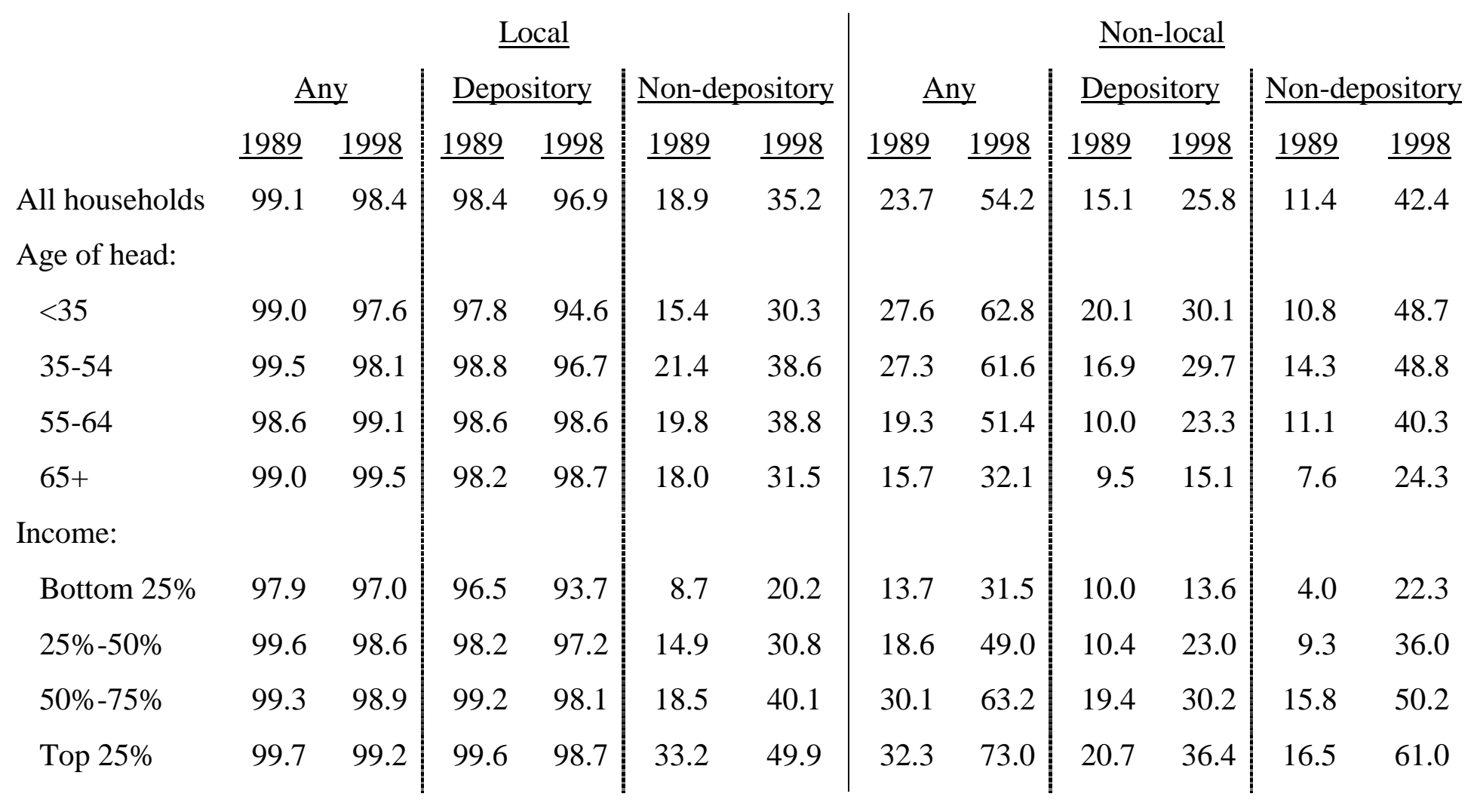


Table 7. Percentage of households using various types of institutions, 1989-1998

Percentage of households using:

\begin{tabular}{lrrrr|rrrrr} 
& \multicolumn{3}{c}{ Primary institution } & \multicolumn{3}{c}{ Non-primary institution } \\
& $\underline{1989}$ & $\underline{1992}$ & $\underline{1995}$ & $\underline{1998}$ & $\underline{1989}$ & $\underline{1992}$ & $\underline{1995}$ & $\underline{1998}$ \\
All institutions & 100.0 & 100.0 & 100.0 & 100.0 & 71.1 & 76.2 & 80.8 & 81.4 \\
& & & & & & & & & \\
Depositories & 96.5 & 96.8 & 96.7 & 95.0 & 64.7 & 67.7 & 67.6 & 64.2 \\
Commercial banks & 64.6 & 71.5 & 70.7 & 67.3 & 36.8 & 45.9 & 47.8 & 46.1 \\
Thrift institutions & 22.4 & 13.3 & 11.3 & 12.1 & 27.2 & 21.5 & 17.1 & 14.5 \\
Credit unions & 9.5 & 11.9 & 14.7 & 15.5 & 22.9 & 26.5 & 27.3 & 24.8 \\
& & & & & & & & & \\
Non-depositories & 3.5 & 3.2 & 3.3 & 5.0 & 25.5 & 40.3 & 50.1 & 59.9 \\
Finance companies & 1.0 & 0.8 & 0.8 & 1.2 & 7.0 & 12.1 & 17.6 & 21.9 \\
Brokerages & 1.3 & 1.1 & 1.6 & 2.5 & 14.0 & 21.7 & 27.6 & 33.5 \\
Mortgage companies & 1.2 & 1.2 & 0.8 & 0.8 & 5.2 & 13.1 & 14.9 & 20.5 \\
Other & 0.0 & 0.2 & 0.2 & 0.5 & 0.9 & 2.1 & 2.1 & 4.5
\end{tabular}


Table 8. Percentages of services acquired from primary institution, 1989-1998

\begin{tabular}{|c|c|c|c|c|}
\hline & $\underline{1989}$ & 1992 & $\underline{1995}$ & $\underline{1998}$ \\
\hline All accounts and loans & 55.8 & 48.6 & 47.9 & 47.3 \\
\hline All accounts & 58.8 & 53.7 & 55.5 & 55.7 \\
\hline Checking & 73.0 & 71.8 & 73.1 & 72.9 \\
\hline Savings & 55.4 & 51.4 & 54.6 & 60.5 \\
\hline Money market & 53.8 & 50.0 & 49.6 & 51.7 \\
\hline CDs & 51.0 & 45.4 & 48.6 & 50.8 \\
\hline IRA/Keogh & 41.1 & 30.7 & 28.3 & 26.2 \\
\hline Brokerage & 18.6 & 11.6 & 11.8 & 12.5 \\
\hline Trusts & 21.5 & 16.4 & 18.7 & 17.9 \\
\hline All loans & 45.3 & 34.1 & 28.8 & 26.0 \\
\hline Mortgages & 39.2 & 32.0 & 24.5 & 22.9 \\
\hline Vehicle & 45.7 & 33.2 & 28.1 & 27.0 \\
\hline Lines of credit & 55.6 & 48.9 & 50.4 & 53.2 \\
\hline Other loans & 52.1 & 29.7 & 27.5 & 16.9 \\
\hline
\end{tabular}


Table 9. Share of households having at least one service of the specified type at primary institutions, by number of services at the primary institution, 1989 and 1998

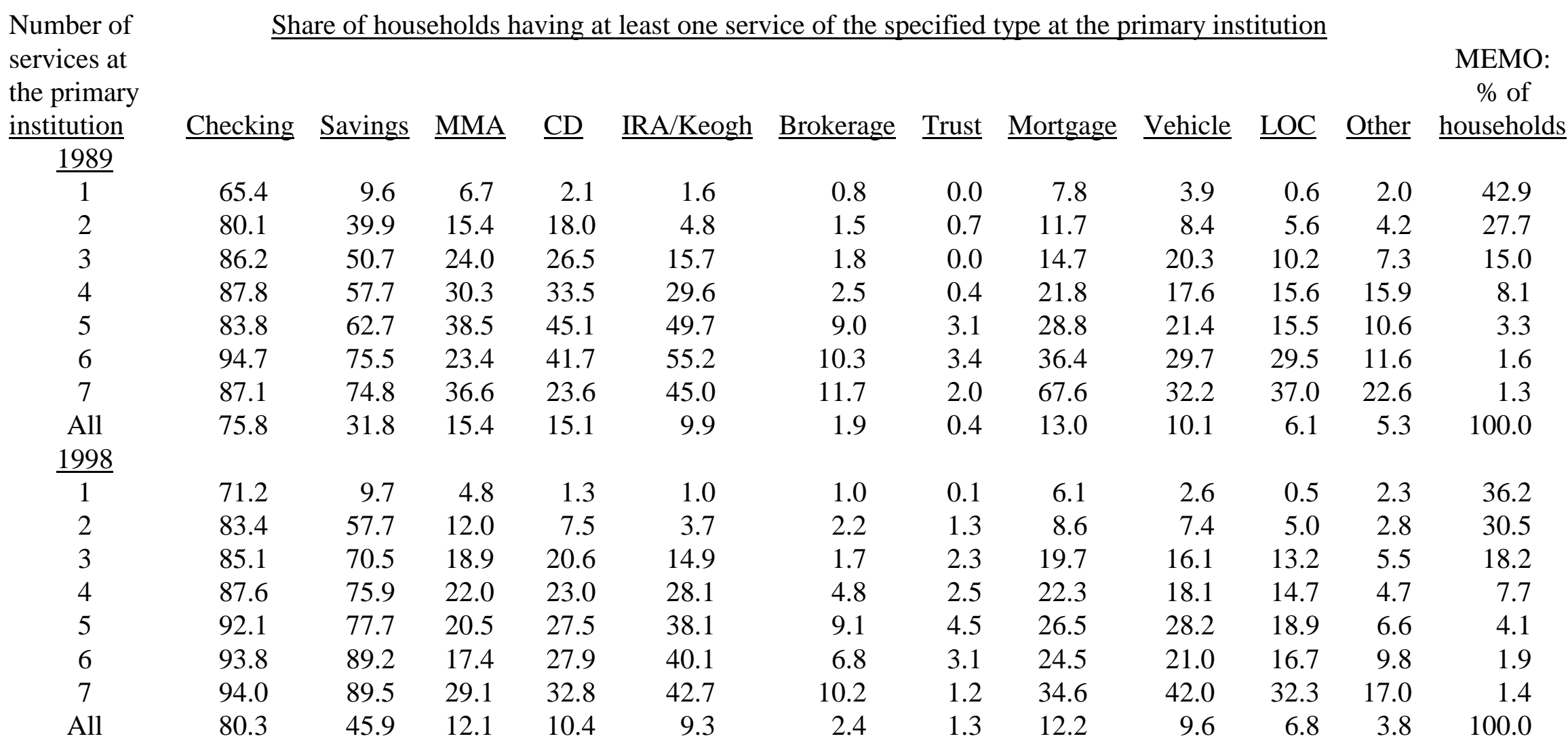

